Vol 1 No 11, November 2021

E-ISSN: 2775-6440 | P-ISSN: 2808-7208

Jurnal Homepage https://fusion.rifainstitute.com

\title{
ANALISIS KINERJA KEUANGAN PADA PT. BUMI SARANA UTAMA MENGGUNAKAN METODE ECONOMIC VALUE ADDED (EVA)
}

\author{
Mansurya, Abdi Akbar Idris, Anwar \\ Program Studi Manajemen Universitas Negeri Makassar \\ Email: mansurya005@gmail.com, anwar@unm.ac.id
}

\begin{abstract}
This study aims to analyze the financial performance of PT. Bumi Sarana Utama during 2015 to 2019 using the method Economic Value Added (EVA). Data collection used using documentation techniques. The results showed that the value of the Economic Value Added (EVA) of PT. Bumi Sarana Utama during 2015, 2016, 2018, and 2019 was negative $(E V A<0)$ which means the company is not able to provide or generate economic added value in its operational activities. Even though they had a positive value in 2017, they could no longer maintain this condition in 2018 and 2019. This was due to a consistent decline in operating profit (NOPAT) and changes in the capital structure whose value fluctuated and tended to decline as a result of the changing urgency of asphalt demand. to the concrete and make the EVA value of PT. Bumi Sarana Utama continues to have a negative trend.
\end{abstract}

Keywords: Economic Value Added, Financial Performance

\begin{abstract}
Abstrak
Penelitian ini bertujuan untuk menganalisis kinerja keuangan PT. Bumi Sarana Utama selama tahun 2015 hingga tahun 2019 dengan menggunakan metode Economic Value Added (EVA). Pengumpulan data yang digunakan menggunakan teknik dokumentasi. Hasil penelitian menunjukkan bahwa nilai Economic Value Added (EVA) PT. Bumi Sarana Utama selama pada tahun 2015, 2016, 2018, dan 2019 bernilai negatif (EVA < 0) yang artinya perusahaan tidak mampu memberikan atau menghasilkan nilai tambah ekonomis dalam kegiatan operasionalnya. Meskipun sempat bernilai positif pada 2017, namun kondisi tersebut tidak bisa mereka pertahankan lagi pada tahun 2018 dan 2019. Hal ini disebabkan oleh penurunan laba operasi (NOPAT) secara konsisten serta perubahan struktur modal yang nilainya fluktuatif dan cenderung menurun sebagai imbas dari berubahnya urgensi kebutuhan aspal ke beton dan membuat nilai EVA PT. Bumi Sarana Utama terus berada pada tren negatif.
\end{abstract}

Kata Kunci: Economic Value Added, Kinerja Keuangan

Diterima: 28-10-2021 Direvisi: 12-11-2021 Diterbitkan: 20-11-2021 


\section{Pendahuluan}

Masalah keuangan merupakan salah satu masalah yang sangat vital bagi dalam perkembangan bisnis di semua perusahaan. Salah satu tujuan utama didirikannya perusahaan adalah untuk memperoleh profit yang maksimal. Namun berhasil tidaknya perusahaan dalam mencari profit dan mempertahankan perusahaannya tergantung pada salah satunya manajemen keuangan. Perusahaan harus memiliki kinerja keuangan yang sehat dan efisien untuk mendapatkan profit atau laba. Olehnya itu, kinerja keuangan merupakan hal yang penting bagi setiap perusahaan di dalam persaingan bisnis untuk mempertahankan perusahaannya (Riswan \& Kesuma, 2014).

Kinerja perusahaan dapat diukur dengan menganalisis dan mengevaluasi laporan keuangan. Informasi posisi keuangan dan kinerja keuangan di masa lalu seringkali digunakan sebagai dasar untuk memprediksi posisi keuangan dan kinerja di masa depan dan hal-hal lain yang langsung menarik perhatian pemakaian seperti pembayaran dividen, upah, pergerakan harga sekuritas dan kemampuan perusahaan untuk memenuhi komitmennya ketika jatuh tempo. Kinerja merupakan hal penting yang harus dicapai oleh setiap perusahaan di manapun, karena kinerja merupakan cerminan dari kemampuan perusahaan dalam mengelola dan mengalokasikan sumber dayanya. Pengukuran kinerja keuangan memberikan penilaian atas pengelolaan aset perusahaan oleh manajemen dan manajemen perusahaan dituntut untuk melakukan evaluasi dan tindakan perbaikan atas kinerja keuangan perusahaan yang tidak sehat (Arifien, 2016).

Alat analisis yang sering digunakan untuk mengetahui kinerja keuangan suatu perusahaan yaitu dengan menggunakan rasio keuangan. Analisis rasio keuangan mempunyai kelemahan yaitu mengabaikan unsur biaya modal. Namun, menurut Maulidiah terdapat beberapa keterbatasan dari analisis rasio. Pertama, rasio keuangan didasarkan atas data laporan akuntansi, sehingga perlu dipertimbangkan atas dasar apakah data tersebut dikembangkan, Kedua, perbandingan dengan data-data atau standar industri tidak menjamin bahwa prestasi perusahaan telah memuaskan dan beroperasi (terkelola) dengan baik. Ketiga, apabila terdapat penyimpangan antara rasio yang telah dicapai oleh perusahaan dengan rasio rata-rata atau standar industri, maka perlu dipertanyakan lebih jauh mengenai faktor yang menyebabkan penyimpangan tersebut. Karena tidak jarang sistem akuntansi yang dipergunakan dalam industri tersebut berbeda antara satu perusahaan dengan perusahaan yang lain. Terakhir, pemilihan metode penilaian persediaan dapat memberikan dampak yang besar terhadap tingkat profitabilitas perusahaan dalam periode inflasi (Maulidiah \& Nasution, 2017).

Merujuk pada berbagai keterbatasan yang telah diuraikan, para ahli kemudian mengembangkan metode lain sebagai alternatif agar dapat menunjukkan seluruh komponen harapan profit yang terukur dalam biaya modal. Salah satunya adalah metode Economic Value Added atau lebih dikenal dengan EVA, yang ditemukan oleh Stern Stewart dan Co. Management Services pada tahun 1990-an. Penilaian kinerja dengan menggunakan pendekatan EVA menyebabkan perhatian manajemen sesuai dengan kepentingan pemilik modal, dimana mereka dalam menginvestasikan dananya ingin mendapat return yang tinggi. Sedangkan bagi manajemen, EVA digunakan untuk 
memilih investasi yang memaksimalkan tingkat pengembalian lebih tinggi dan meminimalkan tingkat biaya modal sehingga perusahaan dapat dimaksimalkan (Indriani, 2018).

EVA ini berkaitan dengan bagaimana kemampuan perusahaan menghitung laba ekonomi secara riil sesuai dengan kriteria dan target perusahaan sehingga pihak manajemen dapat mengetahui sejauh mana keberhasilan yang telah dicapai dalam pengelolaan keuangan dan sebagai dasar dalam penyusunan anggaran atau target pada tahun berikutnya. Penelitian ini kemudian memilih untuk menggunakan Economic Value Added sebagai alat analisis adalah karena adanya urgensi penambahan nilai ekonomis ke dalam target-target yang telah ditetapkan oleh perusahaan. Artinya pencapaian target memanglah menjadi sebuah ukuran paten, namun ketika pencapaian bisa melebihi target maka itulah sebuah pencapaian atau prestasi yang luar biasa. Kelebihan target tersebutlah yang kemudian dikenal sebagai nilai tambah ekonomis.

Nilai tambah ekonomis merupakan perkiraan keuntungan ekonomi perusahaan atau nilai yang dibuat melebihi tingkat pengembalian yang diminta oleh stakeholder (Wisnawa, 2015). Nilai tambah ekonomis muncul dari pemahaman bahwa nilai dibuat dengan asumsi bahwa pengembalian yang lebih tinggi dari ekspektasi atau dengan kata lain melebihi modal kerja yang dialokasikan. Jumlah preferensi nilai tambah ekonomis ini juga harus disesuaikan dengan prinsip akuntansi yang berlaku umum demi tercapainya maksimilasi nilai ekonomis yang signifikan. Maksimalisasi pengembalian tersebut menjadi penting, terutama untuk perusahaan yang belum Go Public seperti PT. Bumi Sarana Utama yang bergerak dibidang penjualan dan distribusi aspal curah dalam upaya meningkatkan profitabilitas dari tingkat investasi yang mereka miliki.

Kegiatan operasional PT. Bumi Sarana Utama tidak lepas dari usaha yang bertujuan untuk memperoleh profit dalam menghasilkan efektifitas dan efisiensi pengelolaan keuangan demi mencapai kinerja keuangan telah ditargetkan. Namun, dalam beberapa tahun terakhir (2015-2018) terjadi penurunan laba operasi secara terus menerus dan juga nilai aset yang berfluktuasi pada periode yang sama. Hal ini menjadi tantangan tersendiri bagi PT Bumi Sarana Utama terkait bagaimana kemudian mereka menstabilkan kembali saldo-saldo akun tersebut agar kiranya kinerja keuangan yang telah mereka targetkan dapat dicapai secara maksimal.

Tabel 1. Keadaan Keuangan PT. Bumi Sarana Utama

\begin{tabular}{ccccc}
\hline Tahun & Total Aset $(\mathrm{Rp})$ & $\begin{array}{c}\text { Perubahan } \\
(\%)\end{array}$ & $\begin{array}{c}\text { Laba Operasi } \\
(\mathrm{Rp})\end{array}$ & Perubahan \\
\hline 2015 & 832.585 & - & 112.549 & - \\
2016 & 800.136 & $(3,89 \%)$ & 62.576 & $(44,40 \%)$ \\
2017 & 983.221 & $22,88 \%$ & 53.202 & $(14,98 \%)$ \\
2018 & 932.894 & $(5,12 \%)$ & 36.152 & $(32,05 \%)$ \\
2019 & 1.097 .522 & $17,65 \%$ & 44.561 & $18,87 \%$ \\
\hline
\end{tabular}

Sumber: Laporan Keuangan PT. Bumi Sarana Utama (Dalam Jutaan Rupiah) 
Berdasarkan data yang telah disajikan pada tabel 1.1 di atas, dapat diketahui bahwasanya terjadi penurunan secara terus menerus pada laba operasi bersih PT. Bumi Sarana Utama yang disebabkan oleh turunnya jumlah penjualan secara signifikan pada medio 2015-2018. Penurunan paling drastis terjadi dari 2015 ke tahun 2016 yakni sebesar 44,40\% atau setara dengan Rp 49,873 Miliar. Selama medio 2015-2018, penurunan pendapatan secara spesifik dikarenakan berkurangnya permintaan aspal curah sebagai dampak dari semakin diliriknya infrastruktur beton dibanding aspal itu sendiri. Dikutip dari laman Program Kota Tanpa Kumuh (KOTAKU) Kementerian Pekerjaan Umum Republik Indonesia pada 19 November 2018, pembangunan infrastruktur seperti jalan dan jembatan kini lebih condong menggunakan beton dibanding aspal dikarenakan beberapa alasan seperti ketahanan terhadap air (banjir) dan kekuatan atas beban berat. Sedangkan dari sisi aspal sendiri meskipun menarik dari segi tampilan dan harganya yang relatif murah dibanding beton, namun belum mampu megimbangi kelebihan yang dimiliki oleh beton. Lebih lanjut, dalam laman tersebut dijelaskan bahwa aspal kini "hanya" dijadikan sebagai bahan perekat beton agar lebih tebal lagi. Artinya, aspal kini hanya menjadi pilihan sekunder di bawah beton, khususnya di wilayah SULAMPUA (Sulawesi, Maluku, dan Papua) di mana PT. Bumi Sarana Utama Beroperasi.

Barulah pada tahun 2019 PT. Bumi Sarana Utama bisa kembali kepada tren laba meningkat sebesar 18,87\% dari tahun 2018. Meskipun belum sesignifikan rata-rata penurunan selama medio 2015-2018 sebelumnya, namun hal ini merupakan sebuah angin segar terkait dengan membaiknya kemampuan menghasilkan laba PT. Bumi Sarana Utama. Peningkatan penjualan ini dikarenakan adanya beberapa proyek strategis pemerintah seperti Jalan Trans Papua yang kembali menjadikan aspal sebagai material utamanya. Kembalinya trend penjualan dan laba positif ini ditandai dengan berbagai penghargaan yang diraih oleh PT. Bumi Sarana Utama seperti Perusahaan Aspal Curah terbaik Se-SULAMPUA dari segi volume penjualan dan pembelian dan berbagai penghargaan lainnya. Sebagai anak perusahaan Kalla Group yang bekerja sama dengan Pertamina, hal ini sudah semestinya terus dipertahankan dan terus ditingkatkan ke depannya (Arifin, 2019).

Dari segi total aset sendiri, terjadi fluktuasi yang bisa dikatakan sangat signifikan di mana terjadi peningkatan sebesar 22,88\% dari tahun 2016 ke 2017. Hal ini dikarenakan adanya peningkatan penerimaan pada akun kas dan setara kas, piutang usaha, serta aset tidak lancar lainnya. Meskipun sempat anjlok lagi sebesar 5,12\% pada tahun 2018, namun PT. Bumi Sarana Utama berhasil menggenjot nilai asetnya sebesar 17,65\%. Fluktuasi jumlah aset ini terjadi karena adanya fluktuasi yang juga terjadi pada saldo akun-akun piutang beserta penyisihannya. Akun-akun piutang ini membuat nilai aset berfluktuasi karena adanya penyesuaian-penyesuaian terhadap penyisihan piutang ragu-ragu yang berubah tiap periode. Hal ini bisa diasumsikan oleh peneliti bahwa PT. Bumi Sarana Utama berhasil terus berupaya untuk memperbaiki aspek-aspek ekonomi pada perusahaannya agar kiranya nilai asetnya terus berada pada trend positif yang 
kemudian diharapkan bisa mempengaruhi segala lini keuangan khususnya pemerolehan laba (Winata, Yuniarta, AK, \& Sinarwati, 2016).

Kembalinya trend pendapatan ke arah yang positif serta saldo aset yang tidak lagi berfluktuasi merupakan sebuah kondisi yang baik tapi bukan berarti PT. Bumi Sarana Utama bisa bernafas lega. Hal ini menjadi tantangan sendiri guna menjaga kondisi demikian sebagai bagian dari mempertahankan nilai tambah ekonomis yang secara tersirat telah berarah positif. Nilai tambah ekonomi ini adalah ketika perusahaan mampu memaksimalkan berbagai potensi (terutama aset) guna memperoleh laba yang sesuai atau bahkan melebihi ekspektasi yang telah ditargetkan. Jika menilik laporan keuangan PT. Bumi Sarana Utama yang disajikan pada tabel 1.1 sebelumnya, terlihat bahwa fluktuasi nilai aset sebagai modal kerja mereka berimbas kepada laba operasi yang dihasilkan selama kurun periode 2015-2018 (Sudiyanto, 2019). Menurunnya permintaan terhadap aspal curah menjadi penyebab utama sekaligus tantangan bagi PT. Bumi Sarana Utama untuk bisa memberikan nilai tambah agar kiranya permintaan aspal curah tetap stabil atau meningkat. Namun hal tersebut tidak berhasil dilakukan selama periode 2015-2018. Padahal sejatinya nilai tambah ekonomis menjadi sangat vital ditengah persaingan pasar dan tuntutan kemajuan zaman saat ini.

Urgensi terkait nilai tambah ekonomis tersebut sejalan dengan hasil penelitian Fatmasari dan Dwiyanto yang dilakukan pada empat perusahaan subsektor pertambangan dan minyak dan gas bumi yang terdaftar dalam Indeks Saham Syariah Indonesia (ISSI) menunjukkan nilai EVA positif bermakna adanya nilai tambah ekonomi bagi perusahaan (Fatmasari \& Dwiyanto, 2019). Pentingnya menambah nilai ekonomis perusahaan juga diungkapkan Lutfiana dalam penelitiannya terkait dengan perusahaan pertambangan yang listing di BEI menemukan bahwa sepanjang 2012-2017 skor EVA yang didapatkan berfluktuasi (kadang dibawah nol dan kadang lebih dari nol) yang artinya kemampuan untuk menambah nilai ekonomisnya juga masih harus ditingkatkan dan terus dipertahankan (Lutfiana, 2013). Dengan demikian ketika kinerja keuangan perusahaan dalam kondisi yang baik, maka tantangan dan juga keharusan untuk berada pada trend itu harus dijaga dan dipertahankan demi kelangsungan hidup PT. Bumi Sarana Utama ke depannya, apalagi jika kondisi kinerja keuangan sedang mengalami penurunan.

\section{Metode Penelitian}

Jenis data yang digunakan adalah data kuantitatif, yakni data yang diukur dengan satuan numerik (angka-angka) (Sugiyono, 2013). Sumber data penelitian ini adalah data sekunder yakni data-data laporan keuangan PT. Bumo Sarana Utama dari tahun 2015-2019. Teknik pengumpulan data yang digunakan adalah teknik dokumentasi. Teknik analisis data yang digunakan adalah metode deskriptif dan analisis rasio. Analisis data dalam penelitian ini dapat dilakukan dengan menyediakan laporan keuangan yang diperoleh dari perusahaan yang bersangkutan meliputi Laporan Posisi Keuangan dan laporan laba-rugi, serta Catatan Atas Laporan Keuangan dan melakukan 
perhitungan rasio keuangan sesuai dengan rumus yang telah ditentukan yakni rumus Economic Value Added (EVA) (Harahap, 2015).

\section{Hasil dan Pembahasan}

\section{A. Perhitungan NOPAT (Net Operating Profit After Tax)}

Tujuan menganalisis Net Operating Profit After Tax (NOPAT) yaitu untuk mengetahui seberapa besar peningkatan laba bersih yang diperoleh laba operasi perusahaan setelah dikurangi pajak penghasilan. Dimana kita dapat melihat berdasarkan laporan keuangan khususnya laba sebelum pajak dan pajak penghasilan PT. Bumi Sarana Utama selama tahun 2015-2019. Berikut disajikan hasil perhitungan NOPAT PT. Bumi Sarana Utama selama tahun 2015-2019:

Tabel 2. Hasil Analisis NOPAT PT. Bumi Sarana Utama (Dalam jutaan rupiah)

Tahun $\begin{gathered}\text { Laba Sebelum Pajak } \\ (\mathrm{Rp})\end{gathered} \quad$ Tarif Pajak 1 -Tarif Pajak $\quad$ NOPAT (Rp)

\begin{tabular}{lrrrr}
\hline 2015 & 112,549 & $20.74 \%$ & $79.26 \%$ & 89,208 \\
2016 & 62,576 & $25.51 \%$ & $74.49 \%$ & 46,614 \\
2017 & 53,202 & $21.20 \%$ & $78.80 \%$ & 41,921 \\
2018 & 36,152 & $24.77 \%$ & $75.23 \%$ & 27,196 \\
2019 & 44,561 & $26.58 \%$ & $73.42 \%$ & 32,717 \\
\hline \multicolumn{5}{l}{ Sumber: Hasil Olahan Data Peneliti (2021) }
\end{tabular}

Berdasarkan data pada tabel 2 di atas, dapat diketahui bahwa Net Operating profit After Taxes (NOPAT) PT. Bumi Sarana Utama selama tahun 2015-2018 terus mengalami penurunan yang disebabkan oleh menurunnya laba bersih sebelum pajak (EBIT) pada periode yang sama. Penyebabnya adalah jumlah penjualan yang menurun yang diakibatkan berkurangnya permintaan terhadap aspal curah dalam periode tersebut. Barulah pada tahun 2019, NOPAT PT. Bumi Sarana Utama kembali meningkat yang dikarenakan kembali meningkatnya laba sebelum pajak pada tahun tersebut. Kenaikan ini sebagai imbas dari kembali meningkatnya permintaan terhadap aspal curah (Oktary, $\underline{2019) .}$

\section{B. Analisis Invested Capital}

Invested Capital merupakan penjumlahan keseluruhan pembiayaan perusahaan. Invested Capital sama dengan penjumlahan ekuitas, liabilitas jangka panjang dan liabilitas lancar, dan liabilitas jangka panjang lainya. Hasil perhitungan invested capital PT. Bumi Sarana Utama ini disajikan pada tabel 3 berikut ini: 
Tabel 3. Hasil Analisis Invested Capital PT. Bumi Sarana Utama (Disajikan dalam jutaan rupiah Invested Capital

Tahun

$$
\text { Total Liabilitas + Total Ekuitas (Rp) Liabilitas Lancar (Rp) } \quad \text { IC (Rp) }
$$

\begin{tabular}{lccc}
\hline 2015 & $1,943,850$ & 355,683 & $1,588,167$ \\
2016 & $1,667,911$ & 229,232 & $1,438,679$ \\
2017 & 983,222 & 363,431 & 619,791 \\
2018 & 932,894 & 278,705 & 654,189 \\
2019 & $1,097,522$ & 365,737 & 731,785 \\
\hline
\end{tabular}

Sumber:Hasil Olahan Data Peneliti (2021)

Berdasarkan data pada tabel 4.2 di atas, diketahui bahwa jumlah modal yang diinvestasikan pada tahun 2015 adalah $R p$ 1,588,167, tahun 2016 sebesar Rp 1,438,679, tahun 2017 sebesar Rp 619,791, 000, tahun 2018 sebesar Rp 654,189,000, dan tahun 2019 sebesar Rp 731,785,000. Dengan demikian, dapat disimpulkan bahwa jumlah modal yang diinvestasikan oleh PT. Bumi Sarana Utama terus mengalami penurunan selama tahun 2015-2018, meskipun total liabilitas dan ekuitas serta jumlah liabilitas lancar yang dikurangi dengan utang bunga senantiasa berfluktuasi.

Fluktuasi tersebut disebabkan oleh tindakan manajemen yang selama tahun 2015-2018 terus berupaya melakukan gebrakan dengan melunasi maupun menambah jumlah modal kerja dari segi liabilitas lancar. Hal tersebutlah yang kemudian mengakibatkan persentase kenaikan total liabilitas dan ekuitas yang lebih besar dibanding liabilitas lancar tanpa utang bunga, begitu juga persentase penurunan yang lebih rendah di sisi yang lain. Hal ini membuktikan bahwa manajemen PT. Bumi Sarana Utama belum mampu mengelola keuangan secara maksimal.

\section{Analisis Struktur Modal}

Biaya penggunaan modal atau biaya modal adalah merupakan konsep yang sangat penting dalam pembelanjaan perusahaan. Konsep ini dimaksudkan untuk dapat menentukan besarnya biaya secara riil harus ditanggung oleh perusahaan untuk memperoleh dana dari suatu sumber. Biaya modal dapat dihitung berdasarkan biaya untuk masing-masing sumber dana atau disebut biaya modal individual. Biaya modal individual tersebut dihitung satu persatu untuk tiap jenis modal. Namun apabila perusahaan menggunakan beberapa sumber modal maka biaya modal yang dihitung adalah biaya modal rata-rata tertimbang (Weighted Average Cost Of Capital disingkat WACC) dari seluruh modal yang digunakan (Maith, 2013). Biaya modal dimaksudkan untuk menentukan besarnya biaya nyata (riil) dari penggunaan dan dari masing-masing sumber dana. Dari biaya modal secara individual tersebut digunakan untuk menentukan biaya modal rata-rata. Sebelum membahas lebih jauh mengenai biaya modal yang dikeluarkan oleh perusahaan, terlebih dahulu akan dikemukakan data berupa beban bunga yang dapat dilihat pada tabel berikut: 


\section{Analisis Tingkat Modal dari Liabilitas}

Analisis ini diperuntukkan untuk melihat berapa jumlah proporsi liabilitas terhadap total liabilitas dan ekuitas. Hasil analisis tingkat modal ini disajikan pada tabel 4.3 berikut ini:

Tabel 4. Hasil Analisis Tingkat Modal PT. Bumi Sarana Utama

\begin{tabular}{cccccc}
\hline \multirow{2}{*}{ Tahun } & Total & \multicolumn{3}{c}{ Liabilitas + Ekuitas } & \multirow{2}{*}{ D } \\
\cline { 3 - 5 } & Liabilitas & Liabilitas & Ekuitas & Total & \\
\hline 2015 & 556,381 & 556,381 & $1,387,469$ & $1,943,850$ & $28.62 \%$ \\
& & & & & \\
2016 & 433,887 & 433,887 & $1,234,024$ & $1,667,911$ & $26.01 \%$ \\
2017 & 583,161 & 583,161 & 400,061 & 983,222 & $59.31 \%$ \\
2018 & 491,727 & 491,727 & 441,167 & 932,894 & $52.71 \%$ \\
2019 & & & & & \\
& 613,344 & 613,344 & 484,178 & $1,097,522$ & $55.88 \%$ \\
\hline
\end{tabular}

Sumber: Hasil Olahan Data Peneliti (2021)

Berdasarkan data pada tabel 4, dapat diketahui bahwa total liabilitas mengalami fluktuasi yang lebih disebabkan kepada jumlah utang bunga bank yang terus mengalami perubahan tingkat suku bunga sehingga mempengaruhi jumlah liabilitas secara keseluruhan. Kebijakan penambahan dan pengurangan modal kerja dari sisi utang juga menjadi salah satu alasan utama terjadinya fluktuasi. Hal ini juga berimbas terhadap total liabilitas dan ekuitas selama periode 2015-2019. Fluktuasi tersebut juga turut mempengaruhi tingkat modal yang dimiliki; Tahun 2015 sebesar 28,62\%, tahun 2016 26,01\%, tahun 2017 $59,31 \%$, tahun $201852,71 \%$, dan tahun 2019 sebesar 55,88\%.

\section{Analisis Biaya Modal dari Liabilitas (Cost of Debt)}

Besarnya biaya modal dari hutang pada PT. Bumi Sarana Utama untuk tahun 2015-2019 dapat dilihat melalui perhitungan sebagai berikut:

Tabel 5. Hasil Analisis Cost of Debt PT. Bumi Sarana Utama

\begin{tabular}{cccc}
\hline Tahun & Beban Bunga & Total Liabilitas & $\mathrm{Kd}$ \\
\hline 2015 & 14,658 & 556,381 & $2.63 \%$ \\
2016 & 10,560 & 433,887 & $2.43 \%$ \\
2017 & 5,765 & 583,161 & $0.99 \%$ \\
2018 & 6,498 & 491,727 & $1.32 \%$ \\
2019 & 13,738 & 613,344 & $2.24 \%$ \\
\hline
\end{tabular}




\section{Sumber: Hasil Olahan Data Peneliti (2021)}

Berdasarkan data pada tabel 5, dapat diketahui bahwa beban bunga yang dimiliki oleh PT. Bumi Sarana bisa dikatakan berfluktuasi selama tahun 20152019. Fluktuasi ini diakibatkan oleh struktur liabilitas jangka panjang yang berubah-ubah selama periode yang sama, terutama utang bank jangka panjang beserta bunga pinjaman yang digunakan untuk membiayai dan menutupi kerugian penurunan penjualan selama periode 2015-2018. Biaya modal dari liabilitas ini paling tinggi pada tahun 2015 2,63\% dan 2016 sebesar 2,43\%.

\section{Analisis Tingkat Modal dari Ekuitas}

Analisis ini bertujuan untuk mengetahui persentase modal yang dimiliki dibandingkan dengan total liabilitas yang dijumlahkan dengan keseluruhan modal biasa. Perhitungan ini disajikan dalam tabel 6 berikut ini:

Tabel 6. Hasil Analisis Tingkat Modal dari Ekuitas PT. Bumi Sarana Utama (Disajikan dalam jutaan rupiah)

\begin{tabular}{crcc}
\hline \multirow{2}{*}{ Tahun } & \multicolumn{3}{c}{ Tingkat Modal/Ekuitas } \\
\cline { 2 - 4 } & Total Ekuitas & $\begin{array}{c}\text { Total Liabilitas }+ \\
\text { Ekuitas }\end{array}$ & E \\
\hline 2015 & $1,387,469$ & $1,943,850$ & $71.38 \%$ \\
2016 & $1,234,024$ & $1,667,911$ & $73.99 \%$ \\
2017 & 400,061 & 983,222 & $40.69 \%$ \\
2018 & 441,167 & 932,894 & $47.29 \%$ \\
2019 & 484,178 & $1,097,522$ & $44.12 \%$ \\
\hline
\end{tabular}

Sumber: Hasil Olahan Data Peneliti (2021)

Merujuk pada sajian data pada tabel 6 di atas, dapat diketahui persentase tingkat modal dari ekuitas yang dimiliki PT. Bumi Sarana Utama selama tahun 2015-2019. Persentase tertinggi ada pada tahun 2016 yakni sebesar 73,99\% yang disebabkan oleh kenaikan total ekuitas dan penurunan total liabilitas dan ekuitas biasa (yang merupakan nilai terendah dalam kurun waktu 5 tahun). Selama tahun 2017-2018, total ekuitas mengalami penurunan yang disebabkan oleh perolehan laba yang juga menurun dalam periode yang sama. Hal tersebut merupakan imbas dari turunnya jumlah penjualan yang berkorelasi penurunan permintaan aspal curah. Sedangkan pada tahun 2019 ekuitas yang dimiliki mengalami kenaikan yang juga diikuti kenaikan pada total liabilitas dan ekuitas.

\section{Analisis Cost of Equity}

Cost Of Equity adalah tingkat pengembalian yang dikehendaki investor karena adanya ketidakpastian tingkat laba. Kewajiban membayar bunga dan pokok hutang membuat laba bersih perusahaan lebih bervariasi (naik turun) dari pada laba operasi, sehingga menyebabkan timbulnya tambahan resiko. Jadi biaya ekuitas ini mencangkup adanya resiko bisnis dan resiko finansial. Resiko bisnis adalah resiko yang berhubungan dengan baik stabilnya laba, sedangkan resiko finansial adalah resiko kesulitan financial dalam hal pembayaran biaya bunga pada pokok hutang (Kaba, Jati, \& Ndoen, 2018). 
Tabel 7. Hasil Analisis Cost of Equity PT. Bumi Sarana Utama (Disajikan dalam jutaan rupiah)

\begin{tabular}{cccc}
\hline \multirow{2}{*}{ Tahun } & \multicolumn{3}{c}{ Cost of Equity } \\
\cline { 2 - 4 } & Laba Setelah Pajak (Rp) & $\begin{array}{c}\text { Total Ekuitas } \\
(\mathrm{Rp})\end{array}$ & $\mathrm{Re}$ \\
\hline 2015 & 112,549 & $1,387,469$ & $8.11 \%$ \\
2016 & 62,576 & $1,234,024$ & $5.07 \%$ \\
2017 & 53,202 & 400,061 & $13.30 \%$ \\
2018 & 36,152 & 441,167 & $8.19 \%$ \\
2019 & 44,561 & 484,178 & $9.20 \%$ \\
\hline
\end{tabular}

Sumber: Hasil Olahan Data Peneliti (2021)

Berdasarkan data pada tabel 7 diketahui bahwa cost of equity PT. Bumi Sarana Utama selama tahun 2015-2019 mengalami fluktuasi yang disebabkan oleh fluktuasi total ekuitas pada periode yang sama. Dari tabel tersebut kita juga dapat melihat bahwasanya laba setelah pajak yang diperoleh oleh PT. Bumi Sarana Utama selama tahun 2015-2018 mengalami penurunan yang disebabkan oleh menurunnya jumlah penjulaan pada periode yang sama, serta baru mengalami kenaikan lagi pada tahun 2019.

\section{Analisis Tingkat Pajak}

Analisis ini digunakan untuk menghitung persentase pajak yang dibayar tiap tahunnya, dengan membagi jumlah beban pajak dengan laba sebelum pajak. Berikut disajikan data perhitungan tingkat pajak PT. Bumi Sarana Utama Tahun 2015-2019:

\begin{tabular}{cccc}
\hline \multirow{2}{*}{$\begin{array}{c}\text { Tahun } \\
\text { u }\end{array}$} & Beban Pajak (Rp) & $\begin{array}{c}\text { Laba Setelah Pajak } \\
(\mathrm{Rp})\end{array}$ & Tax \\
\cline { 2 - 4 } & & 141,997 & $20.74 \%$ \\
\hline 2015 & 29,448 & 84,003 & $25.51 \%$ \\
$\mathrm{~h}_{2016}$ & 21,428 & 67,517 & $21.20 \%$ \\
2017 & 14,316 & 48,058 & $24.77 \%$ \\
$2_{2018}$ & 11,906 & 58,001 & $26.58 \%$ \\
2019 & 15,416 & & \\
\hline
\end{tabular}

Hasil Olahan Data Peneliti (2021)

Berdasarkan data pada tabel 8 dapat diketahui bahwa tingkat pajak yang dibayarkan berbeda-beda tiap tahunnya meskipun pada tahun 2015-2018 beban pajak dan laba setelah pajak mengalami penurunan. Hal ini dikarenakan komponen pendapatan yang berubah-ubah. 


\section{Menghitung WACC}

Setelah semua komponen sebelumnya dihitung, maka selanjutnya dihitung biaya modal rata-rata tertimbang (WACC) Sebagai berikut:

Tabel 9. Hasil Analisis WACC PT. Bumi Sarana Utama

\begin{tabular}{ccccccr}
\hline \multirow{2}{*}{ Tahun } & \multicolumn{6}{c}{ WACC } \\
\cline { 2 - 7 } & $\mathrm{D}$ & $\mathrm{Kd}$ & $1-\mathrm{Tax}$ & $\mathrm{E}$ & \multicolumn{1}{c}{ Ke } & Kalkulasi \\
\hline 2015 & $28.62 \%$ & $2.63 \%$ & $79.26 \%$ & $71.38 \%$ & $8.11 \%$ & $6.39 \%$ \\
2016 & $26.01 \%$ & $2.43 \%$ & $74.49 \%$ & $73.99 \%$ & $5.07 \%$ & $4.22 \%$ \\
2017 & $59.31 \%$ & $0.99 \%$ & $78.80 \%$ & $40.69 \%$ & $13.30 \%$ & $5.87 \%$ \\
2018 & $52.71 \%$ & $1.32 \%$ & $75.23 \%$ & $47.29 \%$ & $8.19 \%$ & $4.40 \%$ \\
2019 & $55.88 \%$ & $2.24 \%$ & $73.42 \%$ & $44.12 \%$ & $9.20 \%$ & $4.98 \%$ \\
\hline
\end{tabular}

Sumber: Hasil Olahan Data Peneliti (2021)

Hasil analisis data pada tabel 9 di atas menggambarkan bahwa WACC PT. Bumi Sarana Utama, diketahui terjadi penurunan secara signifikan dari tahun 2015 ke 2016, namun kembali mengalami kenaikan pada 2017. Sempat turun secara tidak signifikan pada 2018, namun kenaikan yang signifikan kemudian terjadi pada 2019. Fluktuasi WACC ini disebabkan oleh penurunan laba bersih dan jumlah ekuitas yang terus terjadi selama tahun 2015-2018. WACC tertinggi terjadi pada tahun 2015 sebesar 6,39\% dan tahun 2017 sebesar 5,87\%.

\section{Menghitung Capital Charge}

Capital charge didapat dengan mengkalikan WACC dengan invested capital. Capital Charge menunjukkan seberapa besar kesempatan modal yang telah disuntikkan kepada perusahaan. Hasil perhitungan capital charge PT. Bumi Sarana Utama selama tahun 2015-2019:

Tabel 10. Hasil Analisis Capital Charge PT. Bumi Sarana Utama (Dalam jutaan rupiah)

\begin{tabular}{crrr}
\hline Tahun & WACC & \multicolumn{1}{c}{ IC } & \multicolumn{1}{c}{ CC } \\
\hline 2015 & $6.39 \%$ & $1,588,167$ & $101,447.22$ \\
2016 & $4.22 \%$ & $1,438,679$ & $60,760.94$ \\
2017 & $5.87 \%$ & 619,791 & $36,400.32$ \\
2018 & $4.40 \%$ & 654,189 & $28,779.29$ \\
2019 & $4.98 \%$ & 731,785 & $36,436.89$ \\
\hline
\end{tabular}

Sumber: Hasil Olahan Data Peneliti (2021)

Berdasarkan data pada tabel 10, diketahui bahwa capital charge PT. Bumi Sarana Utama selama tahun 2015-2019 mengalami penurunan yang sangat drastis. Hal ini diakibatkan oleh fluktuasi yang cenderung menurun pada persentase WACC dan nilai Invested Capital selama tahun 2015-2018. Barulah pada tahun 2019 kondisi WACC dan juga invested capital kembali pada tren kenaikan signifikan sehingga capital charge-nya juga kembali mengalami kenaikan. 


\section{Analisis $\boldsymbol{E} \boldsymbol{V A}$}

Bagian ini merupakan langkah akhir, di mana hasil analisis Economic Value Added akan diketahui. Perhitungannya adalah mengalikan persentase WACC dengan Capital Charge setiap tahunnya. Berikut disajikan hasil perhitungan EVA PT. Bumi Sarana Utama selama tahun 2015-2019:

Tabel 11 Hasil Analisis EVA PT. Bumi Sarana Utama

\begin{tabular}{cccc}
\hline Tahun & NOPAT & $\begin{array}{c}\text { Capital } \\
\text { Charge }\end{array}$ & EVA \\
\hline 2015 & 89,208 & $101,447.22$ & $(12,239.16)$ \\
2016 & 46,614 & $60,760.94$ & $(14,147.21)$ \\
2017 & 41,921 & $36,400.32$ & $5,520.97$ \\
2018 & 27,196 & $28,779.29$ & $(1,583.67)$ \\
2019 & 32,717 & $36,436.89$ & $(3,719.70)$ \\
\hline
\end{tabular}

Sumber: Hasil Olahan Data Peneliti (2021)

Merujuk pada tabel 11, dapat diketahui pada tahun 2015, 2016, 2018, dan 2019 nilai EVA PT. Bumi Sarana Utama bernilai negatif (EVA < 0) yang menandakan bahwa tidak terjadi proses nilai tambah ekonomis atau dengan kata lain perusahaan tidak mampu menciptakan nilai yang melebihi biaya modal sebagai indikasi kinerja keuangan yang tidak baik. Hal ini dikarenakan nilai NOPAT yang yang terus menurun dan tidak sebanding dengan fluktuasi capital charge. Meskipun pada tahun 2017 NOPAT PT. Bumi Sarana Utama kembali meningkat dan bernilai positif, namun penurunan pada sisi capital charge yang signifikan membuat nilai EVA pada tahun tersebut justru kembali bernilai negatif pada 2018 dan 2019.

\section{Kesimpulan}

Kinerja keuangan PT. Bumi Sarana Utama selama tahun 2015 hingga 2019 yang dianalisis dengan metode Economic Value Added (EVA) tidak mengalami perkembangan karena terus berada pada nilai negatif (EVA $<0$ ). Nilai EVA negatif yang dihasilkan PT. Bumi Sarana Utama disebabkan oleh tingkat biaya modal yang lebih tinggi dibandingkan dengan tingkat pengembalian laba operasi perusahaan. Nilai EVA negatif PT. Bumi Sarana Utama ini merupakan buntut dari nilai penjualan yang turun menurun yang berimbas kepada laba yang dihasilkan, yang tentunya membuat beban keuangan PT. Bumi Sarana Utama terus tertekan utamanya pada tahun 20152018. Nilai negatif ini menjadi indikator ketidakmampuan manajer keuangan untuk memberikan nilai tambah ekonomis sesuai dengan ekspektasi para stakeholder. 


\section{BIBLIOGRAFI}

Arifien, Dian Nur. (2016). Penerapan Teknik Analisis Rasio Keuangan Sebagai Alat Untuk Mengevaluasi Kinerja Keuangan Perusahaan Tambang Yang Tercatat Di Bei (Periode 2009-2014). Jurnal Ilmu Manajemen (JIM), 4(1). Google Scholar

Arifin, Anwar. (2019). Analisis Faktor-Faktor Yang Berpengaruh Terhadap Kinerja Keuangan Perusahaan Otomotif Dan Komponen Yang Terdaftar Di Bursa Efek Indonesia. Prosiding FRIMA (Festival Riset Ilmiah Manajemen Dan Akuntansi), (2), 477-483. Google Scholar

Fatmasari, Endah, \& Dwiyanto, Bambang Sugeng. (2019). Analisis Kinerja Keuangan dengan Metode Economic Value-Added pada Studi Kasus Perusahaan Subsektor Pertambangan Minyak dan Gas Bumi yang Terdaftar di Indeks Saham Syariah Indonesia (ISSI). Jurnal Maksipreneur: Manajemen, Koperasi, Dan Entrepreneurship, 9(1), 17-27. Google Scholar

Harahap, Sofyan Syafri. (2015). Analisis Kritis atas Laporan Keuangan, Cetakan Kedua belas. Jakarta: PT Raja Grafindo Persada. Google Scholar

Indriani, Ayu. (2018). Analisis Kinerja Keuangan Perusahaan yang Terdaftar di Bursa Efek Indonesia (BEI) Sebelum dan Sesudah Akuisisi. Jurnal Ilmu Manajemen, 15(1), 27-36. Google Scholar

Kaba, Tante Meylan A. J., Jati, Hironnymus, \& Ndoen, Wehelmina. (2018). Penilaian Kinerja Keuangan dengan Pendekatan Economic Value Added dan Market Value Added pada Bank Bumn yang Terdaftar di Bursa Efek Indonesia. Journal of Management: Small and Medium Enterprises (SMEs), 6(1), 83-101. Google Scholar

Lutfiana, Lina. (2013). Analisis Kinerja Keuangan Perusahaan dengan Menggunakan Metode Economic Value Added (Eva) dan Metode Market Value Added (MVA)(Studi pada PT Japfa Comfeed Indonesia Tbk. dan PT Charoen Pokphand Indonesia Tbk. di BEI Periode 2009-2011). Jurnal Administrasi Bisnis, 6(1). Google Scholar

Maith, Hendry Andres. (2013). Analisis Laporan Keuangan dalam Mengukur Kinerja Keuangan pada PT. Hanjaya Mandala Sampoerna Tbk. Jurnal EMBA: Jurnal Riset Ekonomi, Manajemen, Bisnis Dan Akuntansi, 1(3). Google Scholar

Maulidiah, Anita, \& Nasution, Ute Chairuz. (2017). Analisis Kinerja Keuangan Perusahaan Dengan Menggunakan Metode EVA (Economic Value Added). Jurnal Dinamika Administrasi Bisnis, 3(1). Google Scholar

Oktary, Dewi. (2019). Analisis Penilaian Kinerja Keuangan Menggunakan Penerapan Economic Value Added (EVA) Dan Market Value Added (MVA) Pada Perusahaan Telekomunikasi Yang Terdaftar Di Bursa Efek Indonesia Periode Tahun 2015- 
2018. Jurnal Ekonomi Integra, 9(1), 17-30. Google Scholar

Riswan, Riswan, \& Kesuma, Yolanda Fatrecia. (2014). Analisis laporan keuangan sebagai dasar dalam penilaian kinerja keuangan PT. Budi Satria Wahana Motor. Jurnal Akuntansi Dan Keuangan, 5(1). Google Scholar

Sudiyanto, Totok. (2019). Analisis Kinerja Keuangan Dengan Menggunakan Pendekatan Economic Value Added (Eva) Pada Pt. Indosat Tbk Yang Terdaftar Di Bursa Efek Indonesia Periode 2010-2014. Jurnal Media Wahana Ekonomika, 13(3). Google Scholar

Sugiyono, Dr. (2013). Metode penelitian pendidikan pendekatan kuantitatif, kualitatif dan $R \& D$. Google Scholar

Winata, Vandi Surya, Yuniarta, Gede Adi, AK, S. E., \& SINARWATI, N. I. KADEK. (2016). Penggunaan analisis kinerja keuangan Perusahaan dengan Pendekatan Economic Value Added (EVA) dan Market Value Added (MVA) pada Perusahaan Manufaktur Yang Go Public di Bursa Efek Indonesia Tahun 2012-2015. JIMAT (Jurnal Ilmiah Mahasiswa Akuntansi) Undiksha, 6(3). Google Scholar

Wisnawa, I. Putu Gargita. (2015). Analisis Laporan Keuangan Dengan Metode Economic Value Adeed Dalam Mengoptimalkan Sisa Hasil Usaha Pada Koperasi Unit Desa Panca Satya Tahun 2011-2014. 5(1). Google Scholar

First publication right:

Jurnal Syntax Fusion: Jurnal Nasional Indonesia

This article is licensed under:

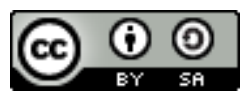

